\author{
Andrii Matviichuk \\ V. I. Vernadskyi National Library of Ukraine (Kyiv, Ukraine) \\ https://orsid. org/oooo-0oo3-4051-2484 \\ e-mail: matvijchuk@nas.gov.ua
}

\title{
VOLUNTEER ORGANIZATIONS WORK AS A DETERMINING MARKER OF CIVIL SOCIETY DEVELOPMENT IN UKRAINE
}

\section{Abstract}

It analyses essential indicators of volunteering, volunteer work and the features of work conducted by volunteer organizations as an index of civic society development in Ukraine. The features of volunteer movements in Ukraine have been analyzed. It has been recognized that Ukrainian volunteer movement in 2014 become an unprecedented manifestation of public self-organization in its scale. The increasing of volunteer movement had been due to two chief factors: internal political crisis, that has led to the disbalance of the public administration systems, lack of quality management decisions, lack of resources, and external aggression which deepened the disbalance between the state's ability to perform its functions effectively and ensuring the basic needs of the citizens. The crisis in the country and external influences had endangered the existence of Ukraine as a state, which has been received by its citizens as a personal challenge, as danger to their self-identification.

It has been demonstrated that volunteer organizations are an influential social institute that acts on a voluntary basis and brings the country income and also solves a number of socially important issues instead of the state administration.

In conclusion, volunteering is steadily becoming a foundation for civil society development. Without the work conducted by the volunteers it is hard to imagine NGOs and charities at all, the quality control over government and business becomes virtually impossible. Without volunteers there is not enough energy to fuel societal development, there's not enough effort and time to help people in need, not enough creative potential for solving social problems.

Keywords: civil society, volunteering, volunteer organizations, volunteer projects, volunteer work 


\section{Матвійчук Андрій Васильович}

Національна бібліотека Украйни імені В. І. Вернадського (м. Київ, Украӥна)

https://orsid. org/oooo-0oo3-4051-2484

e-mail:matvijchuk@nas.gov.ua

\section{ДІЯЛЬНІСТЬ ВОЛОНТЕРСЬКИХ ОРГАНІЗАЦІЙ ЯКДЕТЕРМІНАНТА РОЗВИТКУ ГРОМАДЯНСЬКОГО СУСПІЛЬСТВА В УКРАЇНІ}

\section{Резюме}

Окреслено сучані тенденції розвитку громадських об’єднань та функціонал громадянського суспільства. Проаналізовано сутнісні показники волонтерства, волонтерської діяльності та особливості діяльності волонтерських організацій як індикатора розвитку громадянського суспільства в Україні.

Класифіковано волонтерські організації за: масштабами діяльності, статевою і віковою ознаками, громадянством, порядком фінансування, в залежності від отримувачів волонтерської допомоги, за кількісним складом. Визначені основні обов'язки та спектр волонтерських проектів залежно від видів діяльності, цілей та завдань.

Охарактеризовано специфіку волонтерських рухів в Україні. Засвідчено, що український волонтерський рух, зокрема у 2014 році за масштабом поширення став безпрецедентним виявом громадської самоорганізації. Зростання активності волонтерського руху було обумовлене двома основними факторами: внутрішньополітичною кризою, що призвела до розбалансування системи державного управління, дефіциту якісних управлінських рішень, браку ресурсних можливостей, та зовнішньою агресією, яка поглибила дисбаланс між здатністю держави ефективно виконувати свої функції та забезпеченням основних потреб громадян. Кризові процеси в країні та зовнішні впливи поставили під загрозу існування України як національної держави, що було сприйнято громадянами як особистий виклик, загрозу їх самоідентифікації. 
Продемонстровано, що волонтерські організації є впливовим соціальним інститутом, який, діючи на добровільній основі, приносять дохід державі та вирішує низку суспільно важливих проблем замість держави.

Підсумовується, що волонтерство все більше стає фундаментом розвитку громадянського суспільства. Без участі волонтерів важко уявити громадські організації й благодійність взагалі, без них унеможливлюється якісний суспільний контроль за діями влади та бізнесу. Без волонтерів бракує енергії для будівництва суспільства, не вистачає сил і часу на людей, які потребують допомоги, не достатньо творчого потенціалу для розвязання соціальних проблем.

Ключові слова: громадянське суспільство, волонтерство, волонтерські організації, волонтерські проекти, волонтерська діяльність

\section{Introduction}

Modern civil society recognises the work of volunteer organizations as a means for preservation and enhancement of human values, realisation of human rights and freedom. In most countries, volunteer organizations play an important role in facilitating personal growth through recognition of human potential. It's hard to overestimate the importance of volunteer movement in Ukraine today. It has been the volunteers who became the chief component of qualitative changes in Ukraine in the time of the biggest threat to the sovereignty of Ukraine. Under the military aggression of Russian Federation against Ukraine, especially during the beginning stages, volunteer organizations had given immense support to both the army and the victims of military aggression, had rescued hundreds and thousands of lives and had helped the government to get out of a deep protracted crisis. Taking into account the modern trends of volunteering as a social phenomenon, there is necessity for summing up of the experience and clarification of chief markers of volunteer organizations work as a foundation for active society in Ukraine.

This institute of civil society has been thoroughly researched in scientific works by E. Arato, H. Arendt, V. Bezverkhyi, V. Varyvdin, J. Habermas, E. Gellner, O. Horban, R. Daherndorf, J. Keene, G. Cohen, E. Kolas, O. Larson, R. Putnam, F. Rudysch, L. Salamon, A. Seligman, O. Skrypniuk, R. Hintz, V. Horos, V. Tsvykh, Yu. Shemshuchenko, P. Schmitter, etc. Problematics of collaboration between civil society and non-governmental organizations had been studied by: Ye. Bystrytskyi, A. Bilous, O. Vinnikova, V. Horlenko, M. Hurytska, H. Yevtushenko, A. Karas, V. Kovalchuk, A. Kolodiy, I. Kresina, O. Kriukova, M. Latsyba, A. Liasota, I. Makarova, O. Polishchuk, etc. Features of volunteer work had been studied in works by O. Akymov, A. Åslund, V. Bocharova, R. Vainola, V. Voronova, B. Vulfov, O. Hlavnyka, T. Druzhchenko, I. Zvierieva, A. Kapska, L. Mishchyk, A. Muudryk, H. Myundal, A. Müller-Armack, Ye. Kholostova, D. 
Hepworth, N. Ivchenko, R. Larsen, V. Petrovych, Yu. Polishchuk, N. Romanova, etc.

However, the essential features of volunteer organizations' work and the correlation with the process of development of a functioning civil society in Ukraine has been still under researched. This is what has defined the purpose of this article.

\section{Results}

As the highest form of social being, a human can exist only within the frames of social space that determines the chief and prior role of social factors in the formation and development of humanity. The necessity in a just distribution of public resources has resulted in such a social institution as civil society. Traditionally, such areas of responsibility belong to a civil society: generation and articulation of societal and group interests; cooperation with government bodies in order to legalise such interests; control over development and realisation of state programs on realisation of these interests; systematization of own work through organization process; interaction between different civic structures that have conflicting interests in order to find middle ground; receiving social services at the expense of the state budget; securing civil education. The implementation of deliberate political and modernization instruments (open public discourse, discussions, hearings, etc. ) has resulted in a functional increasement of solving these problems in civic society [1, p. 59].

According to O. Demianenko, modern civil society has following functions (roles): - «the protector» (governing institutions on accounting and promotion of transparency and accountability); - «the advocate» (education on social problems and challenges, as well as facilitation of positive changes); - «the service provider» (providing services for social needs, including in education, health, food and security spheres, as well as managing damage control after natural disasters, rapid response to emergencies); - «the expert» (spreading of unique knowledge and experience to shape politics and strategies, as well as finding constructive solutions); - «the builder» (provision of education, retraining, internship, etc. for capacity building); - «the incubator» (development of long term solutions); - «the representative» (giving voice to marginalized or underrepresented groups); - «the civilian-champion» (encouraging citizens to actively participate in social life and supporting human rights); - «the solidarity supporter» (facilitating propagation and enhancement of fundamental and general values); - «the standard setter» (development of normatives for the market and state activity [2, p. 139].

One of the most important indicators of civil society and the defining marker of the political and social stance of the country is the guaranteed right for unions (non-governmental organizations). Depending on political compass of the country, NGOs may play various roles, such as: 1) NGOs that support 
civic movement; 2) NGOs that act as pressure groups; 3) international NGOs; 4) socially useful organizations; 5) NGOs that act as informational or propagandist outlets [3, p. 197-198].

It is worth noting that the term «non-governmental organization» emphasizes that such organizations are not business entities, their mission is not production of material goods. The title «third sector» emphasizes that they do not belong nor to government, nor to business. It also showcases that NGOs play an important and independent role in society. The last of the mentioned titles - non-governmental organization - highlights that these organizations are created by the citizens themselves and thus «belong» to the society (and not government). As of today, none of the aforementioned titles hasn't been recognised internationally. All of them are in use, and their meaning may differ drastically (a fund in France or USA is a completely different organisation than in Central Europe) [4, p. 4].

To NGOs belong unions that Ukrainian citizens voluntary create in accordance with the Constitution, in order to satisfy and protect their legitimate social interests (achieving legitimate goals); the work of such unions is transparent and open, and profit is not a chief goal, but means for realisation of own statutory functions [5, p. 3].

There are three distinguished types of NGOs:

1. Liberal or anglo-saxon (Great Britain, Switzerland). Researchers include in this type such NGOs that perform most of the social work and still are independent from the state and commercial structures. Such a model is usually caused by the predominant individualism ideology.

2. Continental European model (Austria, Belgium, Italy, Germany, France). This model's features include expanding the role of the state in order to stimulate economic growth, provide social investments and social security programs.

3. Scandinavian (Denmark, Finland, the Netherlands, Norway, Sweden). NGOs in these countries have been majorly founded on expression of interests of various social groups. [6, p. 35].

The active development of a relatively novel for Ukraine phenomenon of volunteering is one of the important consequences of civil society development and NGOs in Ukraine. Having begun as small and unstructured volunteer organizations, whose chief goal had been to aid those in need, during the period of greatest threat to Ukrainian sovereignty, it were volunteer organizations that became the forpost in the fight for rights and freedoms.

It is generally understood that a «volunteer» (lat. "voluntaris»-will, desire) is a person that helps others of their own free will [7, p. 117-123]. The Big explanatory dictionary of official terms gives such a definition: «volunteer is an individual who freely offers to conduct free, disinterested and socially 
important work on his own behalf or on the behalf of a non-governmental organisation» $[8$, p. 221].

Legal definition of the term «volunteer» is defined in Law of Ukraine «On Volunteering». Article 7 of the Law determines a volunteer as an individual who voluntarily carries out socially oriented non-profit activities by providing volunteer assistance [9].

V. Dybailo and Sh. Malerius characterise the term «volunteer work» as human actions that do not bring the person any profit, as it is their own free work for a certain community or society improvement [10, p. 15-20]. K. Sydorenko outlines volunteer work as a «specific form of charity, willful, free, work that is characterized by the volunteer help subject activities in favour of the end receiver of volunteer help for the improvement of their state» [11, p. 8]. Z. Bondarenko notes that under chief volunteer principles are understood basic concepts, regulatory provisions that reflect the most significant, main aspects and manifestations of such work [12, p. 44].

In some countries, volunteer work constitutes a large part of the social and economic spheres, providing solidarity and stability. In others, the volunteer work is less documented. However, everywhere problems related to poverty, violence, drug abuse, HIV / AIDS, pollution, exist and they all need solving that volunteers can provide. Worldwide, the volunteers may be both youth and working people, and pensioners [13, p. 139-144].

The Note by the Secretary-General of the United Nations, addressed to the Commission for Social Development of the UN Economic and Social Council, highlights the most important features of volunteering: caring for people; spiritual quality and civic virtue; rich human experience; new intellectual resources; participation and responsibility as a core of civil position; ethics standard that determines the quality of human relationships; provision of a stable platform for restoring connections between people; new visions of social work [14, p. 61-70].

Thus, volunteering is created based on social connections, cooperation and relationships between individuals, social groups and other communities for realisation of vital needs. The process of volunteering development is an adequate societal reaction to the socio-economic situation, that is characterized not only by impoverishment of a significant part of society, but also by the weakening of the state's potential. At the time, the state has drastically decreased its regulatory and developmental functions in the social sphere, the state system of patronage has weakened considerably. The volunteering being resurrected as a societal reaction to problems existing in a corresponding period of time $[15, \mathrm{p} .10]$.

In societies with an established democratic tradition, the participation of volunteers in realisation of specific goals and task is important not only from the point of view of enlisting unpaid labour, but also in the context of «waking» 162 
in the society such norms and values as altruism, responsibility, helping your neighbour, as opposed to the «values» of a consumerist society [16, p. 5].

It is important to note that first major volunteer organizations started to appear in Europe in the post-World War I period. Their chief objective had been to aid the victims of war. Since then the volunteer movement has gained a major popularity and as of today is widespread in many countries: in France up to $19 \%$ of citizens volunteer, in Germany - 34,0 \% (although starting with 2002, Germany has started counting volunteering as an alternative to army service), in USA - almost 5\%, in Japan - 26\% [17].

All of the volunteering projects specter could be differentiated by the activity types, goals and tasks:

- humanitarian projects - this may be the most widespread specter of volunteer initiatives that includes different types of aid; chiefly socio-advisory and human rights protection services for various social categories - aid to children from troubled families, adaptation of people with disabilities, social rehabilitation of former criminals, etc.;

- ecology projects for environment protection, overcoming the consequences of man-made disasters (oil spills, forest fires, etc), facilitation of national parks and reserves work (e. g. Volunteers In Parks);

- cultural and historical initiatives directed at conservation of historical monuments, cultural heritage of the country in its tangible and intangible manifestations (project «Historical Interpretation Volunteers») [16, p. 8].

M. Shamin lists such volunteer organizations' duties: a) creation of all necessary working conditions for the volunteer; b) explanation to the volunteer their rights and responsibilities; c) ensure safety of the volunteer (conduct safety briefings or, if there is real threat to the volunteer's health and life, provide health insurance); d) providing the volunteer full information on the volunteer organization's work; e) solving conflict situations that arise during the volunteer work process; f) conducting educational seminars and trainings [18, p. 20-25].

V. Sirko suggests the following classification of volunteer organizations and institutions that enlist volunteers to their work:

1) according to the work scale: a) regional (within a certain administrativeterritorial unit); b) national (within the borders of a country); c) international (within several countries);

2) by gender: a) female; b) male: c) mixed;

3) by citizenship: a) national (only citizens of one country); b) volunteer organizations that hire non-citizens;

4) by form of financing: a) subsidized; b) autonomous;

5) by the volunteer aid end receivers: a) organizations that help individuals; b) organizations that protect animals; c) organizations that protect and restore environmental objects; d) organizations that protect, restore and 
preserve cultural heritage, historical and cultural environment, historical and cultural monuments; e) organizations that facilitate the work of governmental and non-governmental bodies;

6) by the age groups of volunteer organizations' participants: a) those which include minors; b) those which include senior citizens; c) those which include only of age people;

7) by the staff quantity: a) small (up to 10 people); b) middle (ranging from 10 to 30 people); c) big (over 30 people) [19, p. 199-200].

Today we can call influential volunteer organizations such bodies:-United Nations Volunteers (UNV) - the organization is directly subordinate to the UN, works on the stable global development on the planet through promotion of volunteering and volunteer mobilization for solving specific practical problems;-Service Civil International (SCI)-founded in 1920, has 33 departments worldwide. It's goal is promotion of peace, international understanding and solidarity, social justice and environment protection. It's main activity is focused on organizing international volunteer project, seminars, volunteer programs of various duration, educational trainings and international exchange; - Youth Action for Peace (YAP) - began its work in 1923 with promoting the idea of peace and cooperation, protests against military conflicts. Has departments in 15 countries. Unites politically active youth, works on organizing volunteer antiwar projects, pacifist seminars and trainings; develops methods on nonviolent resolution of military conflicts, work with refugees, socially unprotected groups, lobbying for anti-war and peacekeeping ideas among political parties and organizations; - International Cultural Youth Exchange (ICYE) - first began its work in 1949, has 30 departments in countries Africa, Asia, Europe and South America. Mission of ICYE is the propagation of youth volunteering for international understanding and peace. Global education and intercultural upbringing are two chief principles of the federation's program on work with children, senior people and people with disabilities, on organization of children centers, ecology projects; - Alliance of European Voluntary Service Organizations was founded in 1982 and is a center for European national volunteer organizations specified on coordination of short and long term volunteer working camps that propagate ideas of international cooperation, peace and mutual aid;-Coordinating Committee for International Voluntary Service (CCIVS)-founded in 1948 under UNESCO. Coordinates work of over 250 national volunteer organization in 100 countries; - Association of Voluntary Service Organization (AVSO) - coordinates work of European volunteer organizations and lobbies interests of volunteering on the governmental, social institutes levels and social organisations [20].

Increasing volunteering in Ukraine in 2013-2014 has resulted in the large-scale research conducted by the UN. The report «Volunteer movement in 164 
Ukraine" states that almost quarter (23\%) of Ukrainians have had volunteering experience, and 9\% have started volunteering during 2014. The chief activity direction in 2014 had been to aid Ukrainian army and to the injured; almost $70 \%$ of volunteers worked in this sub sphere [21].

The results of sociological researches also state that Ukrainian volunteer movement growth in 2014 is an unprecedented manifestation of public selforganization. The increasing of volunteer movement had been due to two chief factors: internal political crisis, that has led to the disbalance of the public administration systems, lack of quality management decisions, lack of resources, and external aggression which deepened the disbalance between the state's ability to perform their functions effectively and ensuring the basic needs of the citizens. The crisis in the country and external influences had endangered the existence of Ukraine as a state, which has been received by its citizens as a personal challenge, the danger to their self-identification [16, c. 16].

So, volunteering is a foundation of a civil society. It is hard to imagine NGOs and charities without volunteers as the quality control over government and business becomes virtually impossible. Without volunteers there is not enough energy to fuel societal development, there's not enough effort and time to help people in need, not enough creative potential for solving social problems [22, p. 65].

For Ukraine, as well as whole world, work of volunteer organizations today is important for such reasons:

1) as the long history of volunteer work showcases, it is an effective way for solving difficult problems of an individual, society and environment that often arise due to lack of sufficient care for the public good;

2) volunteering brings to the social sphere new, as a rule creative and brave ideas on solving most pressing and difficult problems. That is why hopeless, at first glance, situations are being solved;

3 ) volunteering is a means for every member of any given society to take part in improvement of quality of life;

4) it is a mechanism for people to address their troubles to people qualified to aid them [23, p. 96].

As practice in many countries has showcased, volunteer work brings stable income and provides a contribution to GDP of 4 to $8 \%$. And iштсу the very concept of volunteer work is based on free of charge work, for many small non-commercial organizations of various directions the aid of volunteers is crucial. That is why the factor of such a large-scale involvement of citizens volunteering makes the volunteer work an important economic resource on the state level [16, p. 7].

\section{Conclusions}

Volunteering expands opportunities for NGOs. It has been recognised that the volunteer movement solves a number of problem issues instead of the 
state government. Volunteering includes social unity of volunteers, volunteer groups trained to perform one or another activity. One can confidently state that the level of volunteer movement development is directly related to the level of development of a civil society. Volunteer movement in Ukraine has started rapidly developing in 2013-2014. Since then, the volunteer movement has become a major factor for societal activity and an influential political institute of Ukrainian society.

References:

1. Demianenko O. O. (2019). Civil society as a means for political modernization. Doctor's thesis. Kyiv [in Ukrainian].

2. Demianenko O. O. (2016). Role of civil society under globalization. Visnyk NTUU KPI. Politolohiia. Sotsiologiia. Pravo., 3/4 (31-32), 136-142 [in Ukrainian].

3. Dorofeieva V. I. (2018). Constitutional basis for civil unions within the system of human rights protection: Ukraine and international experience. Doctor's thesis. Uzhhorod [in Ukrainian].

4. Stanovskyi K. (1999). Tretiy sektor v demokratychnomy suspilstvi [Third sector in a democratic society]. Lviv: Tovarystvo Leva [in Ukrainian].

5. Yuldashev O. O. (2013). Administrative and legal support of nongovernmental organizations in Ukraine. Doctor's thesis. Kyiv [in Ukrainian].

6. Matvijchuk A. V. (2003). Public associations of entrepreneurs as a subject of self governance. Visnyk Kyivskoho natsionalnoho universytetu im. Tarasa Shevchenka. Seria: Filosofia. Politolohia., 56, 34-38 [in Ukrainian].

7. Krapivina H. O. (2010). Human resources and their motivation for volunteering. Visnyk Lvivskoho instytutu ekonomiky i turyzmu, 5, 117-123 [in Ukrainian].

8. Yu. I. Fedinski (2004) Bolshoy tolkovyy slovar ofitsialnykh terminov [Large explanatory dictionary of official terms]. Moscow: Astrel: AST: Tranzikniga [in Russian].

9. Law of Ukraine № 3236-VI «On Volunteering» revision on 31.08.2018. URL: https://zakon. rada. gov. ua/laws/show/3236-17 [in Ukrainian].

10. Dybailo V., Malerius Sh. (2004). Rozhyrennia mozhlyvostey nederzhavnykh orhanizatsiy cherez zaluchennia volonteriv ta stvorennia merezh [Empovernment of non-governmental organizations through volunteers involvement and creation of networks]. Kyiv [in Ukrainian]. 
11. Sydorenko K. O. (2013). Administrative and legal regulation of volunteering in Ukraine. Extended abstract of candidate's thesis. Zaporizhzhia [in Ukrainian].

12. Ukrainian Philantropist Forum. URL: www. ufb. org. ua [in Ukrainian].

13. Liakh T. L. (2004). Problems of pedagogy technologies. Volunskyi akademichnyi dim, 3-4, 139-144 [in Ukrainian].

14. Liakh T. L. (2006). Historical basis of socio-pedagogic work of volunteers abroad. Volunteering as a resource of social work in a community. Face of a social country in the project «Improvement of social services for children and families in community». Zbirnyk statey mizhanrodnoi naukovoi konferencii dlia studentiv ta aspirantiv (pp 61-70). - Kyiv [in Ukrainian].

15. Marchenko O. V. (2014). Administrative and legal regulation of charity work in Ukraine. Doctor's thesis. Kyiv [in Ukrainian].

16. Volunteer movement: international experience and Ukrainian civil practices. Analitychna dopovid Kyiv: NISD (2015) [in Ukrainian].

17. On volunteering in the world: the United Nations report dated Dec 5 2011. URL: http://www. volunteer. kiev. ua [in Ukrainian].

18. Shamin M. P. (2012) Metodicheskoe posobie po razvitiyu dobrovolcheskoy (volonterskoy) deyatelnosti [Methodology on development of volunteer work]. Kemerovo [in Russian].

19. Sirko V. S. (2018) Administrative and legal support of volunteer work in Ukraine. Extended abstract of candidate's thesis. Odesa [in Ukrainian].

20. Kharchenko S. Ia. (2008). Istoria, teoriia ta praktyka volonterskoho rukhu $\mathrm{v}$ Ukraini [History, theory and practical application of volunteer movement in Ukraine]. Luhansk [in Ukrainian].

21. Ukrainian volunteering is a unique phenomenon. URL: https://www. ukrinform. ua/rubric-society/2324579-ukrainske-volonterstvoavise-unikalne-jomu-zavdacuemo-suverenitetom. html [in Ukrainian].

22. Vashkovych V. V. (2018). Administrative and legal support of volunteering as a one of components of social state functions. Extended abstract of candidate's thesis. Uzhhorod [in Ukrainian].

23. Liakh T. M. (2012). Menedzhment volonterskykh hrup vid A do Ya [Volunteer groups management from A to Z]. Kyiv: Verso-04 [in Ukrainian]. 


\section{Список посилань:}

1. Дем'яненко О. О. Громадянське суспільство як чинник політичної модернізації: дис. ... канд. політ. наук: 23.00.02. Київ. 2019. $208 \mathrm{c}$.

2. Дем'яненко О. О. Роль громадянського суспільства у контексті глобалізаційних процесів. Вісник НТУУ КПІ. Політологія. Соціологія. Право. 2016. Вип. 3/4 (31-32), С. 136-142.

3. Дорофеєва В. І. Конституційні засади участі громадських об’єднань у системі захисту прав людини: Україна та зарубіжний досвід: дис. ... канд. юрид. наук: 12.00.02. Ужгород. 2018. 190 с.

4. Становський К. Третій сектор в демократичному суспільстві. Львів: Товариство Лева, 1999. 20 с.

5. Юлдашев О. О. Адміністративно-правове забезпечення діяльності недержавних громадських організацій в Україні: автореф. дис. ... канд. юрид. наук: 12.00.07. Київ, 2013. 19 с.

6. Матвійчук А. В. Громадські об’єднання підприємців як суб’єкт самоврядування. Вісник Київсъкого національного ун-ту ім. Тараса Шевченка. Серія: Філософія. Політологія. 2003. № 56. C. $34-38$.

7. Крапівіна Г. О. Людські ресурси та їх мотивація в добровольчестві. Вісник Львівсъкого інституту економіки і туризму: $3 б$. наук. ст. Львів: ЛІЕТ, 2010. № 5. С. 117-123.

8. Большой толковый словарь официальных терминов / сост. Ю. И. Фединский. Москва: Астрель: АСТ: Транзиткнига, 2004. $1165 \mathrm{c}$.

9. Закон України № 3236-VI «Про волонтерську діяльність» в редакції від 31.08.2018. URL: https://zakon. rada. gov. ua/laws/ show/3236-17 (дата звернення 31.01.2020).

10. Розширення можливостей недержавних організацій через залучення волонтерів та створення мереж / за ред. В. Дибайло, Ш. Малеріус. Київ, 2004. 98 с.

11. Сидоренко К. О. Адміністративно-правове регулювання волонтерської діяльності в Україні: автореф. дис.... канд. юрид. наук: 12.00.07. Запоріжжя. 2013. 18 с.

12. Всеукраїнський форум благодійників. URL: www. ufb. org. ua (дата звернення 31.01.2020).

13. Лях Т. Л. Волонтерство як суспільний феномен. Проблеми педагогічних технологій: Зб. наук. пр. Луцьк. Волинський академічний дім, 2004. Вип. 3-4. С. 139-144.

14. Лях Т. Л. Історичні засади соціально-педагогічної діяльності волонтерів за кордоном. Волонтерство як ресурс соціальної 
роботи у громаді. Обличчя соціальної держави в рамках проекту «Покращення якості соціальних послуг дітям та сім'ям у громаді»: Зб. ст. міжн. наук. конф. для студентів та аспір. (м. Київ. 22-23 берез. 2006.), 2006. С. 61-70.

15. Марченко О.В. Адміністративно-правове регулювання благодійної діяльності в Україні: дис....канд. юрид. наук: 12.00.07. Київ, 2014. 216 c.

16. Волонтерський рух: світовий досвід та українські громадянські практики: аналіт. доп. Київ: НІСД, 2015. 36 с.

17. Про стан волонтерства у світі: звіт Організації Об’єднаних Націй від 5 грудня 2011 p. URL: http://www. volunteer. kiev. ua (дата звернення 31.01.2020).

18. Шамин М.П. Методическое пособие по развитию добровольческой (волонтерской) деятельности. Кемерово, 2012. 35 с.

19. Сірко В. С. Адміністративно-правове забезпечення волонтерської діяльності в Україні: дис.... канд. юрид. наук: 12.00.07. Одеса. 2018. 218 c.

20. Історія, теорія та практика волонтерського руху в Україні: Наук.навч. - метод. посібник /за заг. ред. С. Я. Харченка. Луганськ: ЛНУ ім. Т. Шевченка, 2008. 319 с.

21. Українське волонтерство - явище унікальне. URL: https://www. ukrinform. ua/rubric-society/2324579-ukrainske-volonterstvoavise-unikalne-jomu-zavdacuemo-suverenitetom. html (дата звернення 31.01.2020).

22. Вашкович В.В. Адміністративно-правове забезпечення волонтерства як складова соціальної функції держави: дис. ... канд. юр. наук: 12.00.07. Ужгород, 2018. 218 с.

23. Лях Т.М. Менеджмент волонтерських груп від А до Я: Навч.метод. посібник. Київ: Версо-о4, 2012. 288 с.

Стаття надійшла до редакції 18.03.2020 р.

(C) Матвійчук A. B., 2020 